\title{
New Record of Feather Mite, Neopteronyssus bilineatus Mironov, 2003 (Arachnida: Pteronyssidae), from a Grey- Capped Pygmy Woodpecker, Yungipicus canicapillus in Republic of Korea
}

\author{
Yeong-Deok Han* (i), Anya Lim, Seokwan Cheong \\ Research Center for Endangered Species, National Institute of Ecology, Yeongyang 36531, Korea
}

\begin{abstract}
This study intended to record a species of feather mite, Neopteronyssus bilineatus Mironov, 2003, (Arachnida: Pteronyssidae), from a grey-capped pygmy woodpecker, Yungipicus canicapillus (Blyth, 1845), in the Republic of Korea. Mite samples were collected from the flight feathers of a woodpecker, preserved directly in 95\% ethyl alcohol, and then observed by a light microscope after specimen preparation. Morphology of Neopteronyssus bilineatus is distinguished from other pici group species by opisthosoma part with 2 longitudinal bends, tarsal seta rlll 3 times longer than tarsus III in males, and 2 elongated hysteronotal plates extending beyond the level of setae e2 in females. In the present study, a species of feather mite, $N$. bilineatus, was newly recorded from $Y$. canicapillus in Korean fauna.
\end{abstract}

Key words: Neopteronyssus bilineatus, grey-capped pygmy woodpecker, feather mite, Korea

Feather mites are generally known as avian commensals and parasites, which inhabit the feathers and/or skin of birds [1-3]. Feather mites usually exhibit a high level of host specificity and spend their entire life cycle in the avian host $[2,4,5]$. Taxonomically, they belong to the superfamilies Analgoidea and Pterolichoidea within the order Sarcoptiformes. More than 2,500 species have been reported worldwide [1]. In Korea, about 52 species of feather mites have been identified except those of the family Pyroglyphidae [6-24].

The genus Neopteronyssus Mironov, 2003 is one of about 23 genera belonging to the family Pteronyssidae Oudemans, 1941 that comprises 17 species, generally associated with woodpeckers of the family Picidae Leach, 1820 [23,25]. The genus Neopteronyssus is classified into 3 species groups, i.e., pici, picinus, and pycnospilus [25]. The differences of these 3 groups are the transventral sclerite of epiandrium and dorsobasal teeth of tarsus IV in males and the shape of hysteronotal shield in females $[23,25,26]$. In the pici group, 5 species, i.e., N. bilineatus Mironov, 2003; N. elongatus (Buchholz, 1869); N. korea-

\footnotetext{
- Received 19 April 2021, revised 5 October 2021, accepted 6 October 2021.

*Corresponding author (kingpanda@nie.re.kr)

(C) 2021. Korean Society for Parasitology and Tropical Medicine

This is an Open Access article distributed under the terms of the Creative Commons

Attribution Non-Commercial License (https://creativecommons.org/licenses/by-nc/4.0) which permits unrestricted non-commercial use, distribution, and reproduction in any

medium, provided the original work is properly cited.
}

nus Han et al. 2019; N. pici (Scopoli, 1763); N. yungipicinus (Mironov, 1987), have been reported in worldwide [23,25].

To date, 9 species of woodpecker in the family Picidae are known to inhabit Korea $[27,28]$. Among these woodpeckers, the grey-headed woodpecker, Picus canus, was reported as the host of N. koreanus in Korea [23]. Therefore, in the present study, we intended to record a species of feather mite, Neopteronyssus bilineatus (Arachnida: Pteronyssidae), from a grey-capped pygmy woodpecker, Yungipicus canicapillus (Blyth, 1845), in Korea.

The carcass of Y. canicapillus (WCC no. 20150389) was provided by the Wildlife Center of Chungbuk (WCC). This woodpecker was initially rescued in Heungdeok-gu (gu=Borough) $\left(36^{\circ} 36^{\prime} 4.84^{\prime \prime} \mathrm{N}, 127^{\circ} 28^{\prime} 44.64^{\prime \prime} \mathrm{E}\right)$, Cheongju-si (si=City), Chungcheongbuk-do (do=Province), South Korea in July 2015, but died during the treatment. Mite samples were collected from its flight feathers, preserved directly in 95\% ethyl alcohol, and then cleared in 10\% lactic acid for a day. The cleared mite samples were mounted on microscope slides in PVA mounting medium (BioQuip, Rancho Dominguez, California, USA) and identified with a Leica DM2500 microscope (Wetzlar, Germany) equipped with DIC (differential interference contrast) optics and microscopic digital camera. Description of the species was given according to the recent format used for species of genus Neopteronyssus [23,25,26]. Morpho- 
logical terminology and nomenclature of leg and idiosomal setae followed Gaud \& Atyeo [29] and Norton [30]. All measurements were in micrometers $(\mu \mathrm{m})$. The classification and scientific names of birds follow Gill et al. [31]. All examined specimens were deposited in the National Institute of Biological Resources (NIBR) with the specimen numbers NIBRIV 0001043151-0001043155.

\section{Description of Neopteronyssus bilineatus Mironov, 2003}

Male $(\mathrm{n}=2)$ : idiosoma 435-448 × 200-215 (length $\times$ width) in size (Fig. 1A). Hysterosoma 270 in length. Prodorsal shield triangular-shape occupying entire prodorsum, weakly sclerotized, posterior margin straight, 139-150 in length along the midline, 145-150 in width of the posterior part (Fig. 2A). Setae c2 filiform, 29-31 in length, the distance between setae se 7071. Subhumeral setae $c 3$ lanceolate, 25-28 ×5.5-6. Distance between prodorsal and hysteronotal shields 1-6 in length along the midline. Hysteronotal shield anterior margin convex, weakly sclerotized, surface without ornamentation, greatest length 280-290, width at the level of anterior margin 150-155 (Fig. 2A). Bases between setae $d 2$ and $e 2$ with a pair of strongly sclerotized longitudinal sclerites, $80-87$ in length. Opisthosomal lobes bluntly rounded; Setae $h 2$ and $h 3$ located on the posterior margin of these lobes. Setae ps 2 situated posterior to setae f2; setae ps2 setiform. Dorsal measurements: $c 2: d 2$ 100, d2: e2 110, d2: gl 37-67, e2: h3 48-49, d1: d2 52, e1: gl 5-6, h2: h2 46-49, h3: h3 35-36, ps1: ps1 19-22. Transventral sclerite absent, inner ends of epimerites IIla shaped as an oblique T, epiandrum absent (Fig. 2B). Genital apparatus 24-28 ×13-18, with genital setae $g$ at the midlevel of this apparatus. Setae $3 a$ slightly located posterior to setae $4 b$. Adanal shield irregular form, with the anterior end of the anal opening. Diameter of anal suckers 18-19. Ventral measurements: $3 a: 4 a$ 43-50, ps3: ps3 30, ps3: h3 50. Tarsus III 60 in length; setae $r$ 3-3.5 times longer than this segment (Fig. 2C). Tarsus IV with 2 acute dorsobasal teeth.

Female ( $\mathrm{n}=3$ ): idiosoma 490-510 $\times 195-208$ (length $\times$ width) in size (Fig. 1B). Hysterosoma 320-355 in length. Prodorsal shield (Fig. 3A): Mostly shaped as in a male, length 150-155, width 145-158. Setae $c 2$ filiform, 32-34 in length; subhumeral setae $c 3$ lanceolate, 26-27 $\times 5-6$. Paired anterior hysteronotal plates situated at the midlevel of hysterosoma, anterior mar-
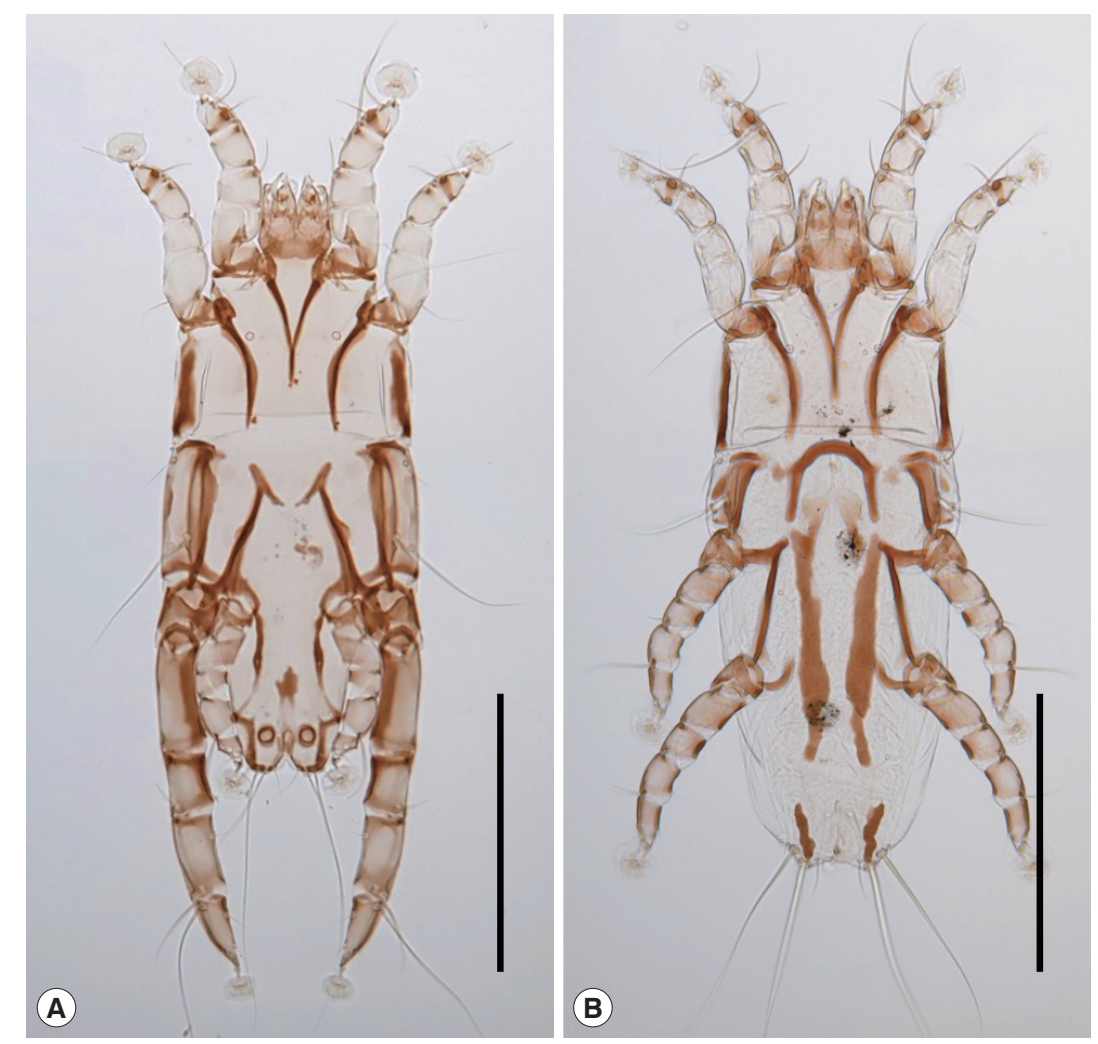

Fig. 1. Neopteronyssus bilineatus recovered from a grey-capped pygmy woodpecker, Yungipicus canicapillus in Korea. (A) Male. (B) Female. Scale bars $=0.2 \mathrm{~mm}$. 
gins extending to the level of setae $c 3$, posterior margins extending beyond the level of setae $e 2$, usually shaped as large longitudinal bends (severe variation in each individual), greatest length 150-190, greatest width 20-24 (Figs. 3A, 4); setae e 1 lateral margins of this plates. Pygidial sclerites small longitudinal shaped, located near the bases of setae $h 2$ and $h 3$, greatest length 13-58, greatest width 8-14. External copulatory tube situated between setae $h 3$, small finger-like. Dorsal measurements: $c 2$ : d2 103-113, d2: e2 113-138, d2: gl 82-120, e2: h3 8190, d2: gl 82-120, h2: ps1 6-8, h2: h2 68-72, h3: h3 54-60. Epigynum semicircular, 63-65 long, 65-75 wide (Fig. 3B). Tarsi III and IV 31-33 and 35-36, respectively.

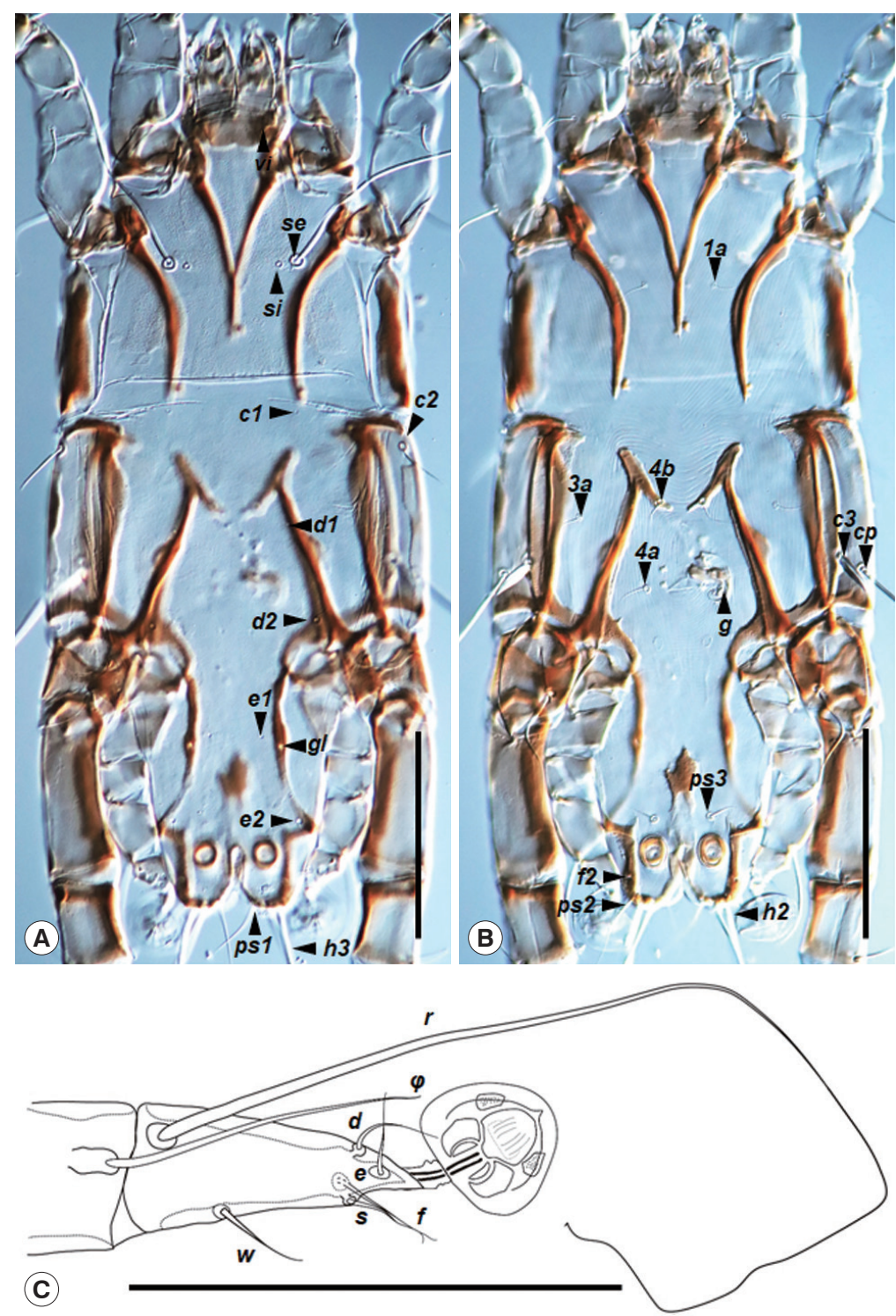

Fig. 2. Neopteronyssus bilineatus, male. (A) Dorsal view of idiosoma, opisthosoma part with 2 longitudinal bends. (B) Ventral view of idiosoma. (C) Tarsus III. Scale bar $=0.1 \mathrm{~mm}$.
Neopteronyssus bilineatus was originally described by Mironov [25] based on specimens collected from Y. canicapillus ( $=D$. canicapillus) in Thailand. In genus Neopteronyssus, males of group pici have common characteristics of opisthosomal lobes small rounded, transventral sclerite and epiandrium absent, tarsi IV with 2 small dorsobasal teeth, and females have the same features as unpaired or paired hysteronotal shields situated at the midlevel of opisthosoma and not extending to poster end of the body [25]. Among 5 species in the pici group, $N$. bilineatus is most similar to $N$. koreanus (Han et al., 2019) and N. yungipicinus (Mironov, 1987) regarding the external traits. However, N. bilineatus clearly differs from N. koreanus 


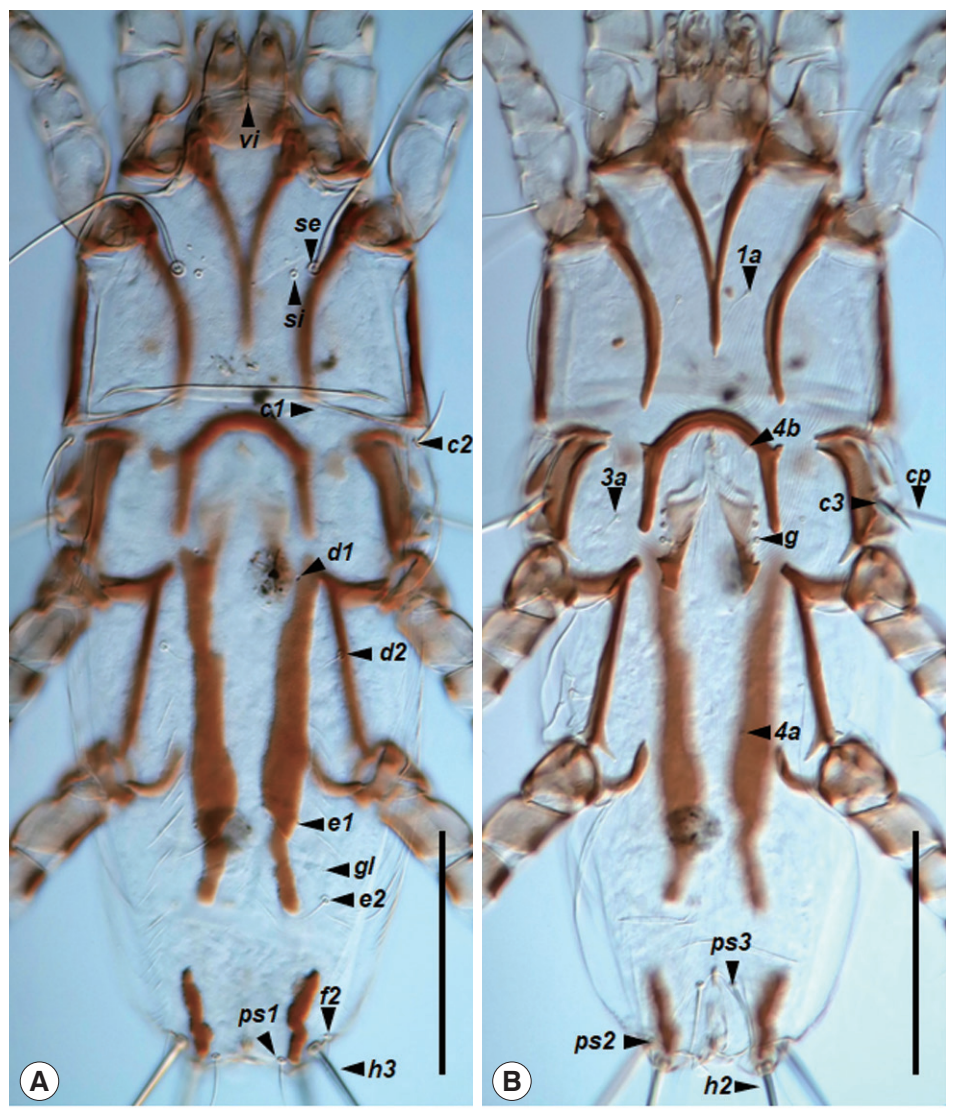

Fig. 3. Neopteronyssus bilineatus, female. (A) Dorsal view of idiosoma, hysterosoma with 2 hysteronotal sclerotized sclerites. (B) Ventral view of idiosoma. Scale bars $=0.1 \mathrm{~mm}$.

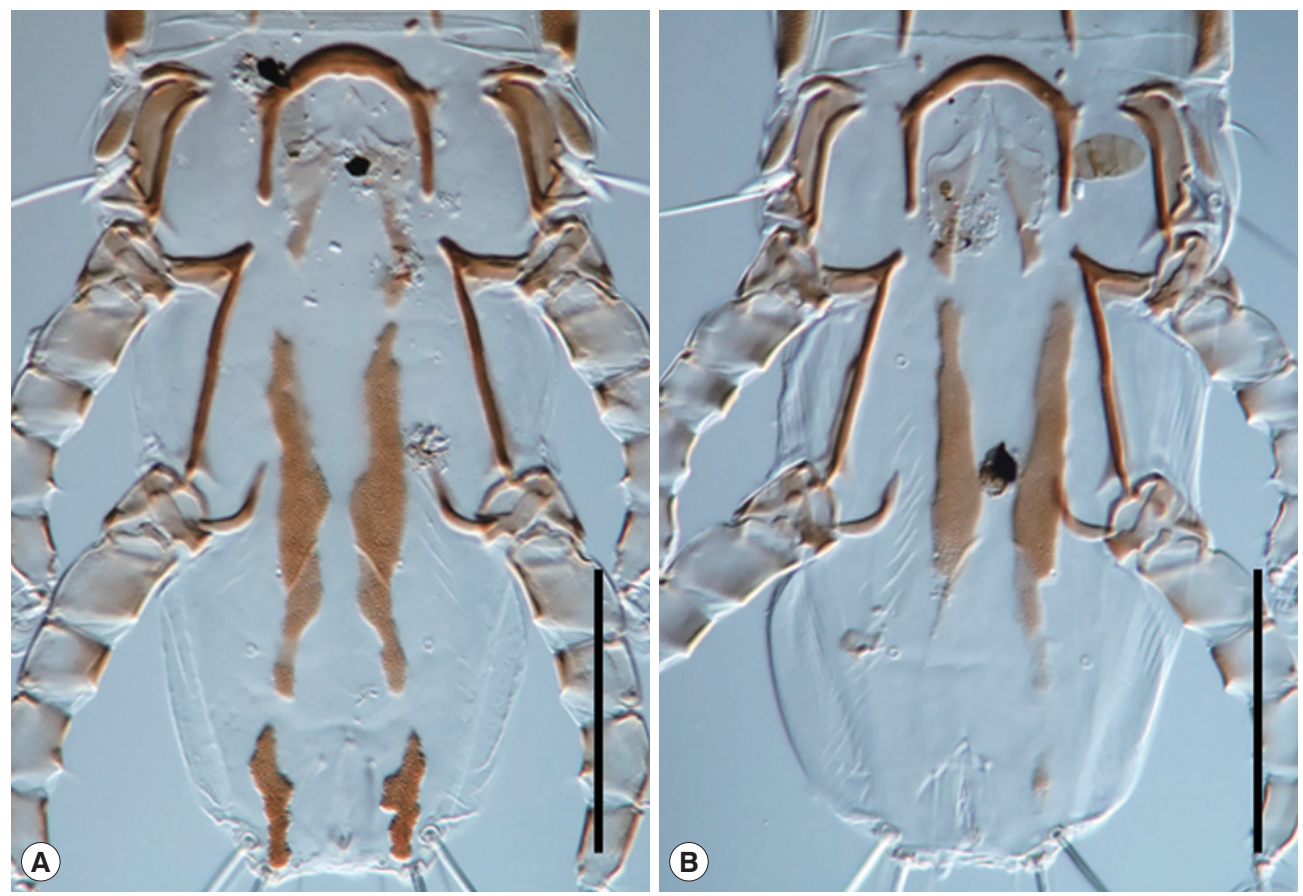

Fig. 4. Variation of hysteronotal plates in females. (A) NIBRIV0001043154. (B) NIBRIV0001043155. Scale bars $=0.1 \mathrm{~mm}$. 
and N. yungipicinus by the following features: in males, the dorsal surface of opisthosoma has longitudinal sclerites, and seta $r$ of tarsus III is 3 times longer than this segment; in females, the anterior margins of hysteronotal sclerotized bands extend to the level of setae $c p$ and the posterior margins of these sclerites extend beyond the level setae $e 2$ [25]. In contrast, in males of N. yungipicinus, the posterior part of hysteronotal shield lacks ornamentation, and the length of seta rIII is 2.5 times shorter than the length of this tarsus; and in females, 2 elongated hysteronotal plates are situated between setae $d 2$ and e2 [25,32]. In addition, hysteronotal shield in males of $N$. koreanus is weakly sclerotized without 2 longitudinal sclerites, and tarsal seta rIII is 1.5 times shorter than tarsus III; in females, pair of anterior hysteronotal plates are located at the level of setae $d 1$ and usually shaped as irregular rectangles (in few specimens, these plates fused by thin sclerite) [23].

In general, $N$. bilineatus found in Korea were morphologically consistent with the original description and illustrations of Mironov [25]. However, the anterior margins of hysteronotal plates in Korean females did not stretch to the level of setae $d 1$. Furthermore, hysteronotal plates of all Korean females are highly varied in length and shape. As the original description was based on 2 female samples, an explanation of individual variation was insufficient. Although females of $\mathrm{N}$. koreanus, a closely related species, show variation in the anterior hysteronotal plates, there was no significant difference in the partial sequences of mitochondrial COI gene (cytochrome $c$ oxidase subunit I) utilized for a DNA barcode [23]. Therefore, we considered this difference as an intraspecific variation in females of N. bilineatus. Accordingly, the hysteronotal plate length of female was not considered a suitable attribute to distinguish the species.

In this study, N. bilineatus was discovered for the first time in Korea. Although some species of feather mites in the genus Neopteronyssus share multiple hosts, most of them show host specificity $[23,25]$. Until now, N. bilineatus has been detected only in Y. canicapillus, distributed in Southeast Asia and Korea $[33,34]$. Therefore, identification of N. bilineatus was chiefly made by the morphological characteristics of mites, and the distribution of host and host specificity were additionally considered in this study.

Conclusively, it was confirmed for the first time that a species of feather mite, $N$. bilineatus, is indigenously infested in $Y$. canicapillus in Korea. Additional studies such as DNA barcoding and morphological comparison of specimens are needed to confirm the intraspecific variation of $N$. bilineatus from Southeast Asia.

\section{ACKNOWLEDGMENT}

The authors wish to thank Prof. Ki-Jeong Na, Dr. Youngsun Lee (Wildlife Center of Chungbuk) for sample collection, and Dr. Sergey V. Mironov (Zoological Institute, Russian Academy of Sciences, Russia) for advice and help in identifying the species.

\section{CONFLICT OF INTEREST}

The authors declare that they have no conflict of interest with this article.

\section{REFERENCES}

1. Mironov SV. On some problems in the systematics of feather mites. Acarina 2003; 11: 3-29.

2. Proctor HC. Feather mites (Acari: Astigmata): ecology, behavior and evolution. Annu Rev Entomol 2003; 48: 185-209.

3. O'Connor BM. Cohort Astigmatina. 3rd ed. In Krantz GW, Walter DE eds, A manual of acarology. Lubbock, Texas. Texas Tech University Press. 2009, pp 565-657.

4. Dabert J, Mironov SV. Origin and evolution of feather mites (Astigmata). Exp Appl Acarol 1999; 23: 437-454. https://doi. org/10.1023/A:1006180705101

5. Mironov SV, Dabert J. Phylogeny and coevolutionary trends in feather mites of the subfamily Avenzoariinae (Analgoidea: Avenzoariidae). Exp Appl Acarol 1999; 23: 525-549. https://doi. org/10.1023/A:1006132806010

6. Atyeo WT, Gaud J. A new genus of feather mites near Proctophyllodes Robin, 1877 (Analgoidea: Proctophyllodidae). Georgia Entomol soc 1971; 6: 43-50.

7. Peterson PC. The feather mite family Alloptidae Gaud III. The Echinacarinae, new subfamily (Acarina, Analgoidea). Steenstrupia 1972; 2: 197-205.

8. Atyeo WT. Feather mites. In McClure HE, Ratanaworabhan N eds, Some Ectoparasites of the Birds of Asia. Bangkok, Thailand. Jintana Printing Ltd.1973, pp 54-78.

9. Atyeo WT, Peterson PC. The species of the feather mite family Rectijanuidae (Acarina: Analgoidea) [Duck parasites]. J Georgia Entomol soc 1976; 2: 349-366.

10. Santana FJ. A review of the genus Trouessartia (Analgoidea: Alloptidae). J Med Entomol Suppl 1976; 1: 1-128. https://doi. org/10.1093/jmedent/13.Suppl1.1

11. Hwang ID, Jong PC, Choi KS. A study on the feather mites (Analgesidae) in Korea. The Chonbuk University Medical Journal 
1986; 10: 11-21 (in Korean).

12. Sohn BO, Noh YT. Feather mites of Kramerellidae and Pterolichidae in Korea (Acari, Pterolichoidea). Korean J Parasitol 1994; 32: 75-83. http://dx.doi.org/10.3347/kjp.1994.32.2.75

13. Sohn BO, Noh YT. Systematic studies of feather mites in Korea Family Analgidae (Acari, Analgoidea). Korean J Entomol 1994; 24: 81-91 (in Korean).

14. Sohn BO. Three new species of the feather mite genus Analges (Analgoidea: Analgidae) from passeriform birds from Korea. Int J Acarol 1995; 21: 27-32. https://doi.org/10.1080/01647959508684040

15. The Korean Society of Systematic Zoology. List of Animals in Korea (excluding insects). Seoul, Korea. Academy Press. 1997, pp 158-159.

16. Han YD, Song JH, Min GS. New record of two feather mites (Acari: Saroptiformes: Astigmata) from Korea. J Species Res 2016; 5: 324-332. https://doi.org/10.12651/JSR.2016.5.3.324

17. Han YD, Min GS. New record of four Korean feather mites (Acari: Sarcoptiformes: Pterolichidae) isolated from the birds in the family Rallidae. J Species Res 2017; 6: 152-163. https://doi.org/ 10.12651/JSR.2017.6(S).152

18. Han YD, Choe S, Eom K S, Min, GS. New record of two Korean feather mites (Acari: Sarcoptiformes: Astigmata) isolated from water birds. J Species Res 2017; 6: 177-184. https://doi.org/10.12651/ JSR.2017.6(S).177

19. Han YD, Min GS. Three feather mites (Acari: Sarcoptiformes: Astigmata) isolated from Tringa glareola in South Korea. J Species Res 2019; 8: 215-224. https://doi.org/10.12651/JSR.2019.8.2.215

20. Han YD, Min GS. New record of two feather mites (Acari: Sarcoptiformes: Astigmata) isolated from Actitis hypoleucos in South Korea. J Species Res 2019; 8: 225-232. https://doi.org/10.12651/ JSR.2019.8.2.225

21. Han YD, Min GS. Four unrecorded species of genus Alloptes (Acari: Sarcoptiformes: Alloptidae) from charadriiform birds in South Korea. Anim Syst Evol Divers 2019; 35: 63-72. https://doi. org/10.5635/ASED.2019.35.2.005

22. Han YD, Min GS. Three feather mites (Acari: Sarcoptiformes) isolated from black-tailed godwit, Limosa limosa in Korea. Anim Syst Evol Divers 2019; 35: 105-113. https://doi.org/10.5635/ASED. 2019.35.3.006

23. Han YD, Mironov SV, Min GS. Two new feather mites (Acari:
Analgoidea) isolated from the grey-headed woodpecker, Picus canus (Piciformes: Picidae) in Korea. Syst Appl Acarol 2019; 24: 2167-2183. https://doi.org/10.11158/saa.24.11.9

24. Mironov SV. A new species of the feather mite genus Analges Nitzsch, 1818 (Acariformes: Analgidae) from the streaked spiderhunter Arachnothera magna (Passeriformes: Nectariniidae), with a renewed diagnosis and world checklist to the genus. Acarina 2019; 27: 19-43. https://doi.org/10.21684/0132-8077-201927-1-19-43

25. Mironov SV. A review of feather mites of the genus Neopteronyssus (Astigmata Pteronyssidae) associated with woodpeckers (Piciformes: Picidae) of the Old World. Belgian J Entomol 2003; 5: 37-77.

26. Mironov SV. Taxonomic corrections to the feather mite genera Pteronyssus Robin, 1877 and Parapteronyssus Faccini et Atyeo, 1981 (Analgoidea, Pteronyssidae). Acarina 2002; 10: 137-147.

27. Lee WS, Koo TH, Park JY. A Field Guide to the Birds of Korea. 2nd ed. Seoul, Korea. LG Evergreen Foundation. 2015.

28. Park JG. Identification Guide to Birds of Korea. Seoul, Korea. Nature and Ecology Publication. 2014, pp 369 (in Korean).

29. Gaud J, Atyeo WT. Feather Mites of the World (Acarina, Astigmata): the Supraspecific Taxa. Belgium. Musee Royal De L'Africque Central. 1996, pp 1-193.

30. Norton RA. Morphological evidence for the evolutionary origin of Astigmata (Acari: Acariformes). Exp Appl Acarol 1998; 22: 559-594. https://doi.org/10.1023/A:1006135509248

31. Gill F, Donsker D, Rasmussen P. IOC World Bird List (v 11.2). International Ornithologists' Union 2021. https://doi.org/10.14344/ IOC.ML.11.2

32. Mironov SV. Three new feather mite species of the family Avenzoariidae (Sarcoptiformes: Analgoidea). Parazitologiya 1987; 21: 528-536.

33. Bi D, Ding H, Wang Q, Jiang L, Lu W, Wu X, Zhu R, Zeng J, Zhou S, Yang X, Kan X. Two new mitogenomes of Picidae (Aves, Piciformes): Sequence, structure and phylogenetic analyses. Int J Biol Macromol 2019; 133: 683-692. https://doi.org/10.1016/ j.ijbiomac.2019.04.157

34. Higuchi H. Colonization and coexistence of woodpeckers in the Japanese Islands. J Yamashina Inst Ornithol 1980; 12: 139-156. https://doi.org/10.3312/jyio1952.12.3_139 